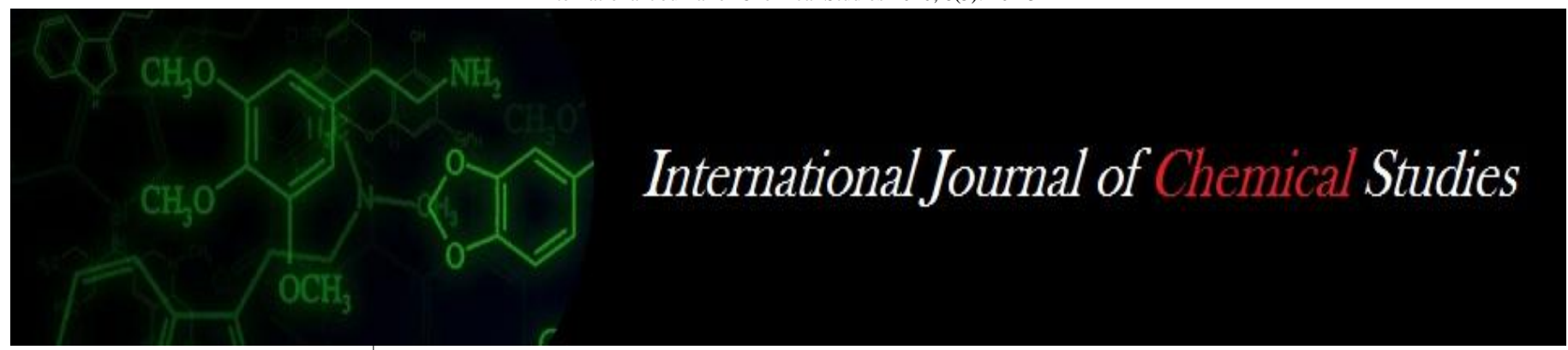

P-ISSN: 2349-8528

E-ISSN: 2321-4902

www.chemijournal.com

IJCS 2020; 8(5): 40-43

(C) 2020 IJCS

Received: 12-08-2020

Accepted: 21-09-2020

\section{Diptanu Das}

M.V. Sc Scholar, Department of Animal Nutrition, College of Veterinary Science \& A.H, CAU, Mizoram, India

\section{AK Samanta}

Professor, Department of Animal Nutrition, College of Veterinary Science \& A.H, CAU, Mizoram, India
Corresponding Author: Diptanu Das

M.V. Sc Scholar, Department of Animal Nutrition, College of

Veterinary Science \& A.H, CAU, Mizoram, India

\section{Effect of processing techniques on chemical composition and hydrogen cyanide content in rubber seed (Hevea brasiliensis) meal}

\author{
Diptanu Das and AK Samanta
}

DOI: https://doi.org/10.22271/chemi.2020.v8.i5a.11004

\begin{abstract}
An experiment was carried out to find out the suitable physical processing method to reduce HCN level of rubber seed meal. Rubber seed was processed and analysed for proximate composition. Chemical composition $(\mathrm{g} / \mathrm{kg})$ of raw rubber seed was found to have $11.64 \%$ crude protein, $21.58 \%$ crude fat and $23.70 \%$ crude fibre. The seeds were processed by three physical methods to check the level of principle anti nutritional factor i.e. Hydro cyanic acid ( $\mathrm{HCN})$. These physical processing includes overnight soaking, boiling for one hour and oven drying at $100 \pm 2^{\circ} \mathrm{C}$ and stored for 21 days. It was observed that physical processing of rubber seed meal did not have significant effect on chemical composition. HCN level was estimated at different days of storage period i.e. $0,7^{\text {th }}, 14^{\text {th }}$ and $21^{\text {st }}$ day after the treatment. $\mathrm{HCN}$ content of the raw rubber seed was found to be $387 \mathrm{mg} / \mathrm{kg}$. After different physical processing methods, the level of HCN was reduced and ranged between 129.6 to $259 \mathrm{mg} / \mathrm{kg}$. Overnight soaking was found to be suitable processing method to reduce the HCN level of Rubber seed meal.
\end{abstract}

Keywords: Rubber seed meal, HCN, processing method, soaking, boiling, oven-drying

\section{Introduction}

It is not possible to overemphasise the value of expanded livestock production in developing countries.In order to ensure that affordable energy and protein is provided for the everincreasing population of developing countries, livestock breeders, animal nutritionists and poultry farmers have roles to play (Aguihe et al., 2017) ${ }^{[1]}$. However, as a result of high prices and competition between humans and animals, the growing production costs involved have not made this feasible (Taiwo et al., 2005 and Annongu et al., 2006) ${ }^{[2,3]}$. Increasing livestock feed costs and the lack of traditional proteins and energy concentrates for feed formulation have forced the animal nutritionists to look for desirable, cheaper and easily accessible protein and energy sources in developing countries.

Rubber seed is an unconventional concentrate sourcecontained substantial amount of proximate components. Rubber seed is the sub-product of natural rubber cultivation (Hevea brasiliensis) which is widely available in certain states of the country (Deng et al., 2015) ${ }^{[4]}$. While rubber seed provides a significant amount of protein and other nutrients, farmers do not use it in livestock diets due to the lack of scientific information on the use of rubber seed in livestock feed and the existence of an anti-nutritional element, i.e. HCN. According to Aguihe et al. (2017) ${ }^{[1]}$ the main constraint in the use of rubber seed is the presence of this hydrocyanic acid. Narahari and Kothandaraman (1983) ${ }^{[5]}$ observed that the rubber seeds kernel contained $749 \mathrm{mg}$ hydrocyanic acid per $\mathrm{kg}$ of seed. This hydrocyanic acid can be detoxified by different physical, chemical and biological methods and the processed rubber seed meal can be used in the diet of livestock. Kinh et al. (2006) ${ }^{[6]}$ processed rubber seed into a useful pig feed and observed that the optimal processing method was to de-hull, de-fat, mixing with water (1:5), which eliminated almost the $98 \%$ of $\mathrm{HCN}$ in rubber seed meal then sundry or dry in drier. Ly et al. (2001) ${ }^{[7]}$ evaluated nutrients of rubber seed meal in Mong Cai pigs and recorded that approximately by 45 days of storage the cyanide content of the rubber seeds decreased from 82.5 to $29.3 \mathrm{mg} / \mathrm{kg}$ DM. The findings of the different workers regarding the HCN content of processed rubber seed are inconsistent. Therefore, the present study was conducted to find out the suitable and practically feasible physical processing method to reduce the HCN level in order to utilize it as pig feed. 


\section{Materials and Methods}

Procurement and preparation of rubber seed meal

The fruit of the rubber tree has a 3-lobed, 3-seeded ellipsoid capsule and 1 seed for each carpel. The seeds are ellipsoidal, colour is mottled brown, $2.5-3 \mathrm{~cm}$ long, variable in size, lustrous and weighing 2-4 g each. For our experiment rubber seed was procured from the farmers of the state Tripura. All the procured rubber seeds were hammer-milled prior to experimental processing to produce the respective meals as soaked RSM (SRSM), boiled RSM (BRSM) and oven dried RSM (ORSM).

\section{Chemical analysis}

Rubber seed meal were analyzed (AOAC, 2000) ${ }^{[8]}$ for dry matter (DM; method 934.01), CP (method 968.06; Kelplus, Pelican Equipments, Chennai, India), crude fiber (CF; Fibre plus, Pelican Equipments, Chennai, India) and ether extract (EE; method 920.39; Socsplus, Pelican Equipments, Chennai, India). All the samples for the analysis were weighed using an electronic balance (Model No.ABS 220-4, Kern \& Sohn $\mathrm{GmbH})$.

\section{Processing of RSM}

Soaking: The collected rubber seed was subjected to grinding followed by overnight (18-20 hrs) water soaking, sun drying and stored for 21 days. While in storage the dried rubber seed meal was checked for the HCN level at 0 day, $7^{\text {th }}$ day, $14^{\text {th }}$ day and $21^{\text {st }}$ day.

Boiling: Rubber seed was boiled for $1 \mathrm{hr}$ after grinding followed by sun drying and stored for 3 weeks. Level of HCN was estimated by following standard procedure (AOAC, $1995)^{\text {[9] }}$ at 0 day, $7^{\text {th }}$ day, $14^{\text {th }}$ day and $21^{\text {st }}$ day while in storage.

Heat treatment: In this method, rubber seed was subjected to grinding followed by dry heating at $100 \pm 2^{\circ} \mathrm{C}$ for 60 minutes and stored up to 21 days. Level of $\mathrm{HCN}$ was checked at 0 day, $7^{\text {th }}$ day, $14^{\text {th }}$ day and $21^{\text {st }}$ day while in storage.

\section{Results and Discussions \\ Proximate Composition of Fresh/raw and Processed Rubber Seed Meal}

The rubber seed used in the present study was analysed for proximate principles before and after different physical processing method in the laboratory and are presented in Table No.1.

The crude protein value of fresh/raw rubber seed meal in the present study were similar to the observation made by Narahari and Kothandaraman (1984) ${ }^{[10]}$, Ly et al. (2001) ${ }^{[7]}$, Tean et al. (2002) ${ }^{[11]}$ and Oyewusi et al. (2007) ${ }^{[12]}$. They found the crude protein content as 11.50, 14.94, 12.19 and $10.30 \%$ respectively. However, the crude protein value in the present study contradicts with Sharma et al. (2014) [13], Suprayudi et al. (2014) ${ }^{[14]}$, Hossain et al. (2015) ${ }^{[15]}$, Khatun et al. (2015) [16], Pha-obnga et al. (2016) [17], Aguihe et al. (2017) ${ }^{[1]}$, Deng et al. (2017) ${ }^{[18]}$, Ahaotu (2018) ${ }^{[19]}$, Udo et al. (2018) ${ }^{[20]}$, Kouakou et al. (2018) ${ }^{[21]}$, Oluodo et al. (2018) ${ }^{[22]}$, Farr et al. (2019) ${ }^{[23]}$, who reported higher values in their experiments.

The ether extract of RSM was similar to the observation made

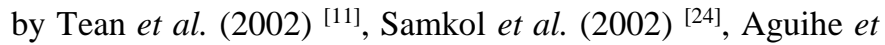
al. (2017) [1], Oluodo et al. (2018) ${ }^{[22]}$ and Kouakou et al. (2018) ${ }^{[21]}$ but lesser than the values observed by Chanjula et al. (2011) ${ }^{[25], ~ S h a r m a ~ e t ~ a l . ~(2014) ~}{ }^{[13]}$, Suprayudi et al.
(2014) ${ }^{[14]}$, Pha-obnga et al. (2016) ${ }^{[17]}$ and Udo et al. (2018) [20], and higher than the values observed by Hossain et al. (2015) ${ }^{[15]}$, Khatun et al. (2015) ${ }^{[16]}$, Khatun and Khan (2015) ${ }^{[26]}$ Deng et al. (2017) ${ }^{[18]}$, Ahaotu (2018) ${ }^{[19]}$ and Farr et al. (2019) ${ }^{[23]}$. The variation in the crude protein and ether extract content can be attributed to rubber tree varieties, or may be climatic condition.

The crude fibre value was similar to the findings of and Khatun and Khan (2015) ${ }^{[26]}$ but higher than the values reported by Sharma et al. (2014) ${ }^{[13]}$, Suprayudi et al. (2014) ${ }^{[14]}$, Khatun et al. (2015) ${ }^{[16]}$, Deng et al. (2017) ${ }^{[18]}$, Aguihe et al. (2017) ${ }^{[1]}$, Udo et al. (2018) ${ }^{[20]}$, Ahaotu (2018) ${ }^{[19]}$ and Farr et al. (2019) [23] and lower than the values reported by Hossain et al. (2015) ${ }^{[15]}$. In the present study, the total ash in RSM was found to be similar to the findings of Sharma et al. (2014) [13], Suprayudi et al. (2014) ${ }^{[14], ~ H o s s a i n ~ e t ~ a l . ~(2015) ~}$ [15], Khatun et al. (2015) [16], Khatun and Khan (2015) ${ }^{[26],}$ Pha-obnga et al. (2016) ${ }^{[17]}$ and Farr et al. (2019) ${ }^{[23]}$ but lesser than the observation made by Chanjula et al. (2011) ${ }^{[25]}$, Deng et al. (2017) ${ }^{[18]}$, Oluodo et al. (2018) ${ }^{[22], ~ U d o ~ e t ~ a l . ~(2018) ~}$ ${ }^{[20]}$, Aguihe et al. (2017) ${ }^{[1]}$ and Ahaotu (2018) ${ }^{[19]}$. The NFE value was similar to the values reported by Udo et al. (2018) ${ }^{[20]}$ and Deng et al. (2017) ${ }^{[18]}$ and contradicts with Suprayudi et al. (2014) ${ }^{[14]}$, Hossain et al. (2015) ${ }^{[15]}$, Khatun and Khan (2015) ${ }^{[26]}$ and Aguihe et al. (2017) ${ }^{[1]}$.

After processing the seeds, there was no such change in the crude protein content of soaked, boiled and oven-dried rubber seed meal. Ether extract and crude fibre values have been lower in processed rubber seed meals than in fresh/raw seed meal, suggesting that during the processing of rubber seeds, some of these nutrients may have been lost. However, nitrogen free extract was higher in all the processed RSM than the fresh/raw RSM. The total ash amount was higher in ORSM and BRSM than the values obtained in fresh/raw rubber seed meal and SRSM.

Table 1: Proximate constituents (g/kg DM) of RSM after physical treatment

\begin{tabular}{|c|c|c|c|c|}
\hline Attributes & $\begin{array}{c}\text { Fresh/raw } \\
\text { RSM }\end{array}$ & SRSM & BRSM & ORSM \\
\hline Moisture & $63.88 \pm 0.45$ & $88.66 \pm 0.38$ & $95.20 \pm 0.36$ & $95.31 \pm 0.26$ \\
\hline DM & $936.12 \pm 0.45$ & $911.34 \pm 0.38$ & $904.80 \pm 0.36$ & $904.69 \pm 0.26$ \\
\hline Crude protein & $116.40 \pm 2.72$ & $114.60 \pm 2.55$ & $113.80 \pm 2.58$ & $117.16 \pm 0.66$ \\
\hline OM & $976.09 \pm 0.48$ & $982.00 \pm 0.19$ & $971.77 \pm 0.63$ & $971.27 \pm 0.43$ \\
\hline Ether extract & $215.80 \pm 1.35$ & $187.60 \pm 1.34$ & $159.60 \pm 1.64$ & $200.60 \pm 2.49$ \\
\hline Crude fibre & $237.06 \pm 2.09$ & $175.60 \pm 1.34$ & $159.80 \pm 1.26$ & $229.00 \pm 1.21$ \\
\hline Total ash & $23.91 \pm 0.48$ & $18.00 \pm 0.19$ & $28.23 \pm 0.63$ & $28.73 \pm 0.43$ \\
\hline Nitrogen free extract & $406.84 \pm 1.67$ & $504.20 \pm 4.5$ & $538.57 \pm 3.76$ & $424.51 \pm 2.63$ \\
\hline
\end{tabular}

\section{HCN content of the fresh/raw RSM and processed RSM}

The HCN levels of RSM were determined after different processing method and are presented in Table No.2. The HCN level was checked after soaking, boiling and dry heating at different day of storage period after treatment i.e. $7^{\text {th }}, 14^{\text {th }}$ and $21^{\text {st }}$ day and was found to be in the range of $129.60 \pm 1.72$ to $187.00 \pm 2.97$ for soaked, $144.00 \pm 4.40$ to $198.00 \pm 3.27$ for boiled and $201.60 \pm 1.78$ to $259.00 \pm 3.36$ for oven dried. However, the storage of fresh / raw rubber seeds can also reduce the hydrogen cyanide content. In the present study, the hydrogen cyanide content of the fresh/raw RSM was 387 $\mathrm{mg} / \mathrm{kg}$, which was similar with the observation of Sharma $e t$ al. (2014) ${ }^{[13]}$ and contradict the value reported by Thuy and Ly (2002) ${ }^{[27]}$, Tean et al. (2002) ${ }^{[11]}$, Suprayudi et al. (2014) ${ }^{[14]}$, Eka et al. (2010) [28], Kouakou et al. (2018) [21], Phaobnga et al. (2016) ${ }^{[17]}$, Ly et al. (2001) ${ }^{[7]}$, Farr et al. (2019) ${ }^{[23]}$ and Aguihe et al. (2017) ${ }^{[1]}$. 
Because of genetic and environmental factor, season, location and soil conditions, cyanogenic glycosides can vary widely (Ermans et al., 1980) ${ }^{[29]}$. Moreover, reductions in hydrogen cyanide $(\mathrm{HCN})$ levels were effective with the implemented treatment approaches and this revealed that on 0 day cyanide level in the fresh/raw seed reduced by $51.68 \%, 48.84 \%$ and $33.07 \%$ for soaking, boiling and oven-drying respectively. The higher concentration of hydrogen cyanide reduced in the SRSM and BRSM were in agreement with the reports from previous researchers (Udo et al., 2016, Farr et al., 2019 and Nambisan. 1994) ${ }^{[20,23,30]}$ that soaking and boiling tends to reduce the RSM HCN concentration.

Table 2: HCN level (mg/kg) of RSM after physical processing method

\begin{tabular}{|c|c|c|c|c|}
\hline Period & Fresh/raw RSM & SRSM & BRSM & ORSM \\
\hline Day-0 & $387.00 \pm 2.92$ & $187.00 \pm 2.97$ & $198.00 \pm 3.27$ & $259.00 \pm 3.36$ \\
\hline Day-7 & $376.00 \pm 2.85$ & $169.20 \pm 1.59$ & $194.40 \pm 4.16$ & $252.00 \pm 2.5$ \\
\hline Day-14 & $359.00 \pm 2.93$ & $143.60 \pm 2.32$ & $176.40 \pm 2.74$ & $244.80 \pm 1.37$ \\
\hline Day-21 & $344.00 \pm 1.96$ & $129.60 \pm 1.72$ & $144.00 \pm 4.40$ & $201.60 \pm 1.78$ \\
\hline
\end{tabular}

\section{Conclusion}

The findings of this experiment revealed that water soaking caused substantial reduction in hydrogen cyanide content in the rubber seeds without change of chemical composition and overnight soaked and dried rubber seed meal may be utilized as pig feed.

\section{References}

1. Aguihe PC, Kehinde AS, Ospina-Rojas CI, and Murakami AE. Evaluation of Processing Methods of Rubber (Hevea brasiliensis) Seed Meal for Use as a Feed Ingredient for Broiler Chickens. J Poult. Res 2017;14(1):20-27.

2. Taiwo AA, Adejuyigbe AD, Adebowale EA, Oshotan JS, David OO. Performance and nutrient digestibility of weaned rabbits fed forages supplemented with concentrate. Niger. J. Anim. Prod 2005;32(1-2):74-78.

3. Annongu AA, Ogundun NJ, Joseph KJ, Awopetu V. Changes in chemical composition and bioassay assessment of nutritional potentials of almond fruit waste as an alternative feedstuff for livestock. Biokemistri 2006;18(1):25-30

4. Deng J, Mai K, Chen L, Mi H, Zhang L. Effects of replacing soybean meal with rubber seed meal on growth, antioxidant capacity, non-specific immune response, and resistance to Aeromonas hydrophila in tilapia (Oreochromisniloticus $\times$ O. aureus). Fish Shellfish Immunol 2015;44(2):436-444.

5. Narahari D, Kothandaraman $P$. The influence of processing and storage on hydrogen cyanide and tannin contents of para-rubber seed and its products. Anim. Feed Sci. Tech 1983;9(4):319-323.

6. Kinh LV, Kopinski JS, Burren B, Ninh PH, Trung VN. Processing rubber seed into a useful pig feed. XII ${ }^{\text {th }}$ AAAP Animal Science Congress. Bexco, Busan, Korea, September 2006, 18-22.

7. Ly J, Ty C, Phiny C. Evaluation of nutrients of rubber seed meal in Mong Cai pigs. Livest. Res. Rural Dev 2001;13(2).

8. AOAC. Official Methods of Analysis. 17th edn., Association of Official Analytical Chemists, Washington DC 2000.
9. AOAC. In Natural Toxins (49 ${ }^{\text {th }}$ chapt.). Official Methods of Analysis of AOAC International, 16th Edn., Vol. II, Virginia, USA 1995, 37-49.

10. Narahari D, Kothandaraman P. Chemical composition and nutritional value of para-rubber seed and its products for chickens. Anim. Feed Sci. Technol 1984;10(4):257267.

11. Tean B, Sath K, Samkol P, Ly J. Utilization by pigs of diets containing Cambodian rubber seed meal. Livest. Res. Rural Dev 2002;14(1).

12. Oyewusi PA, Akintayo ET, Olaofe O. The proximate and amino acid composition of defatted rubber seed meal. J. Food Agric. Environ 2007;5(3/4):115.

13. Sharma BB, Saha RK, Saha H. Effects of feeding detoxified rubber seed meal on growth performance and haematological indices of Labeo rohita (Hamilton) fingerlings. Anim. Feed Sci. Tech 2014;193:84-92.

14. Suprayudi MA, Inara C, Ekasari J, Priyoutomo N, Haga Y, Takeuchi T, et al. Preliminary nutritional evaluation of rubber seed and defatted rubber seed meals as plant protein sources for common carp Cyprinuscarpio L. juvenile diet. Aquac. Res 2014;46(12):2972-2981.

15. Hossain ME, Karim MH, Alam S, Nath SK. Nutritive value of rubber seed (Hevea brasiliensis). Online J. Anim. Feed Res 2015;5:18-21.

16. Khatun MJ, KarimMZ, Das GB, Khan MKI. Effect of the Replacement of Soybean Meal by Rubber Seed Meal on Growth, Economics and Carcass Characteristics of Broiler. Iran. J. Appl. Anim. Sci 2015;5(4):919-925.

17. Pha-obnga N, Aiumlamai S, Wachirapakorn C. Nutritive value and effect of different levels of rubber seed kernel in total mixed ratio on digestibility using In Vitro gas production technique. Asia. Pac. J Sci. Technol 2016;21(3):51-62.

18. Deng J, Chen L, Mai K, Mi H, Zhang L. Effects of replacing soybean meal with rubber seed meal on digestive enzyme activity, nutrient digestibility and retention in tilapia (Oreochromisniloticus $\times$ Oreochromisaureus). Aquac. Res 2017;48(4):1767-1777.

19. Ahaotu E. Nutritional Evaluation of Rubber Seed Meal with Blood Meal in Broiler Rations. Int. J Anim. Sci 2018;2(3):1026.

20. Udo MD, Ekpo U, Ahamefule FO. Effects of processing on the nutrient composition of rubber seed meal. J Saudi Soc. Agric. Sci 2018;17(3):297-301.

21. Kouakou NDV, Angbo-Kouakou CEM, Koné GA, Yeboué FP, Kouadio KB. Enhancement of rubber seeds (Hevea brasiliensis) in pig feeding in Ivory Coast. Proceeding of International Rubber Conference and IRRDB Annual Meetings, Sofitel Abidjan, Côte d'Ivoire $2018,32$.

22. Oluodo LA, Huda N, Komilus CF. Potential Utilization of Rubber Seed Meal as Feed and Food. Int. J. Eng. Technol 2018;7(4.43):64-71.

23. Farr HM, Donkoh A, Boateng MK, Mensah KB. Evaluation of methods of processing rubber seed meal in terms of chemical composition and energy value. Livest. Res. Rural. Dev 2019;31(6).

24. Samkol P, Sovanno P, Preston TR, Ly J. Digestibility studies in growing pigs fed diets based on full-fat rubber seeds or soya beans supplemented with water spinach. Livest. Res. Rural Dev 2002;14:6.

25. Chanjula P, Siriwathananukul Y, Lawpetchara A. Effect of feeding rubber seed kernel and palm kernel cake in combination on nutrient utilization, rumen fermentation 
characteristics, and microbial populations in goats fed on Briachiaria humidicola hay-based diets. Asian Australas J Anim. Sci 2011;24(1):73-81.

26. Khatun MJ, Khan KIK. Different types of maize silage and unconventional feed resources and their nutritive values. Forage Res 2015;41(1):1-9.

27. Thuy NT, Ly J. A short-term study of growth and digestibility indices in Mong Cai pigs fed rubber seed meal. Livest. Res. Rural Dev 2002;14(2):35-37.

28. Eka HD, Tajul AY, Wan NWA. Potential use of Malaysian rubber (Hevea brasiliensis) seed as food, feed and biofuel. Int. Food Res. J 2010;17(3):527-534.

29. Ermans AM, Mbulamoko NM, Delange F, Ahluwalia R. Role of Cassava in the Etiology of Endemic Goitre and Cretinism. International Development Research Centre, Ottawa, Ontario, Canada 1980.

30. Nambisan B. Evaluation of the effect of various processing techniques on cyanogen content reduction in cassava. ActaHortic 1994;375:193-202. 